\title{
Accountability and Management Transparency Masjid Finance Based on Principles Aman and Fathanah (Phenomenology Study in Mosques in Nganjuk Hamlet, Sugihwaras Village, Wonomulyo District, Polewali Mandar Regency, West Sulawesi Province)
}

\author{
SAIFUL MUCHLIS* \\ Faculty of Economics and Business Islamic UIN Alauddin Makassar \\ ANNA SUTRISNA SUKIRMAN \\ Accounting Department of Ujung Pandang State Polytechnic

\section{RIDWAN} \\ Faculty of Economics and Business Islamic UIN Alauddin Makassar
}

\begin{abstract}
This research is based on the antipasti community to the mosque management who usually do not understand financial management and are less transparent. This study aims to determine the application of accountability and transparency of mosque financial management based on the principles of trust and fathanah at Istiqomah Sugihwaras mosque. This research is a type of qualitative research. This study uses the Phenomenology approach where this research is carried out by explaining the existing phenomena by developing concepts and gathering facts through data as a means of supporting and seeing and relating to the reality that is in its implementation.

The results of this study indicate that, Accountability and financial transparency of the Istiqomah Sugihwaras Mosque is in good condition, and is accountable to fellow administrators, mosque worshipers and to Allah. Judging from the Friday share report, Friday's Charity Box report, and monthly donors have been arranged as well as possible and announced every Friday. Istiqomah Mosque does not apply the principle of fathanah as seen from the ordinary court structure and dual positions in the mosque management so that the financial management of the mosque is not good. Transparency of the Istiqomah Mosque only relies on announcements every Friday before Friday prayers. So it is very necessary for training or guidance in financial management, especially non-profit financial institutions and is very much needed with the use of media such as notice boards as a means to communicate the results of the performance of takmir mosques.
\end{abstract}

Keywords: Accountability, Transparency, Amanah and Fathanah

*Corresponding author: saiful.cahayaislam@gmail.com 
Intisari: Penelitian ini didasarkan pada komunitas antipasti kepada manajemen masjid yang biasanya tidak memahami manajemen keuangan dan kurang transparan. Penelitian ini bertujuan untuk mengetahui penerapan akuntabilitas dan transparansi pengelolaan keuangan masjid berdasarkan prinsip kepercayaan dan fathanah di masjid Istiqomah Sugihwaras. Penelitian ini adalah jenis penelitian kualitatif. Penelitian ini menggunakan pendekatan Fenomenologi di mana penelitian ini dilakukan dengan menjelaskan fenomena yang ada dengan mengembangkan konsep dan mengumpulkan fakta melalui data sebagai sarana mendukung dan melihat serta berkaitan dengan kenyataan yang ada dalam implementasinya.

Hasil penelitian ini menunjukkan bahwa, Akuntabilitas dan transparansi keuangan Masjid Istiqomah Sugihwaras dalam kondisi baik, dan bertanggung jawab kepada sesama administrator, jamaah masjid dan kepada Allah. Menilai dari laporan saham hari Jumat, laporan Kotak Amal hari Jumat, dan donor bulanan telah diatur sebaik mungkin dan diumumkan setiap hari Jumat. Masjid Istiqomah tidak menerapkan prinsip fathanah seperti yang terlihat dari struktur pengadilan biasa dan posisi rangkap dalam pengelolaan masjid sehingga pengelolaan keuangan masjid tidak baik. Transparansi Masjid Istiqomah hanya bergantung pada pengumuman sholat Jum'at sebelum Jumat. Jadi sangat diperlukan untuk pelatihan atau panduan dalam manajemen keuangan, terutama lembaga keuangan nirlaba dan sangat dibutuhkan dengan penggunaan media seperti papan pengumuman sebagai sarana untuk mengkomunikasikan hasil kinerja masjid takmir.

Kata Kunci: Akuntabilitas, Transparansi, Amanah dan Fathanah

\section{Introduction}

\subsection{Background}

Preliminary surveys show that many funding sources to finance mosque activities are closely related to the amount of funds managed by mosque administrators. The large amount of funds requires good and healthy financial management, given the mandate delegated from the pilgrims to the mosque administrators, so that they use the funds, and manage them as well as possible. One characteristic of good financial management is the existence of accountability and transparency in financial management.

The people who are antipathetic towards mosque administrators, are caused by their lack of transparency in presenting financial statements. The management of mosque finances is not good, causing many mosque worshipers to come out. The problem is that there are still many mosques that do not record in detail cash receipts 
and disbursements, which are recorded only to the extent of cash receipts and disbursements, without specifying the sources of cash income and the use of mosque cash for anything, so sometimes this raises suspicion among the community (pilgrims). This reality inspires the management of accountability and transparency in mosque finance, using the principles of amanah and fathanah.

In its management, the mosque management is demanded to have a fathanah (smart) principle. Someone who has fathanah character, his decisions show the color of the proficiency of someone who is professional, based on moral attitudes or noble character (Maulana, 2008). So that with these characteristics the mosque administrators will be more wise and smart in handling these sources of income. To carry out the mandate given, it also takes great courage from the mosque administrators, whatever the risks and challenges, in the effort of amar ma'ruf nahi mungkar.

Accountability is a way of accountability of management or recipient of trust to the trustee for the management of resources entrusted to him either vertically or horizontally (Endahwati, 2014). Trust is related to morals such as honesty, patience and courage. This is in line with the start of the democratic era in which the demands of the public for financial accountability and transparency of public and non-profit sector organizations are getting bigger (Bastian, 2015). Accountability arises as a result of giving trust (trust) from one party to another to carry out certain tasks. In Islam, accountability is a philosophy of trust (Kholmi, 2012).

Amanah means trustworthy. The relationship between trustees and trustees is a source of accountability. Mosques as an Islamic religious organization must adhere to the principle of accountability in carrying out their activities. This is due to the belief or trust given by the ummah to the mosque's takmir to manage the entrusted funds to be of positive benefit to the public interest. The form of mosque accountability according to Ansar and Mukhtar (2010), Diptayana (2009) is through the application of accounting in recording financial transactions, managing trust funds according to their objectives, making reliable financial reports and others. 
The higher the accountability in the management of mosque finance, the greater the potential for receiving funds into the mosque (Hag, 2013). In Islam, the concept of trust is very important and has great consequences for people who ignore the mandate. This research is based on the mandate and fathanah principles formulated in the management of mosque finances, namely in the form of accountability and transparency in the management of mosque finance, in order to run as it should and regain a sense of public trust in the mosque's financial managers. This research was carried out at the Istiqomah Mosque in Sugihwaras Village.

\subsection{Formulation of the Problem}

Based on the above background, the rumors of the problem in this study are as follows:

1. How is the implementation of the accountability and transparency of mosque finance based on the principle of trust?

2. How is the implementation of the accountability and transparency of mosque finance based on fathanah principles?

\subsection{Research Purposes}

The objectives of this study are as follows:

1. To find out how the implementation of mosque financial transparency is viewed from the principle of trust.

2. To find out how the application of the accountability and transparency of mosque finance is viewed from the principle of fathanah.

\section{Literature Review}

\subsection{Syariah Interprise Teory}

Sharia InterpriseTeory according to Triyuwono (2001) is God as the Sole Creator and Owner of all the resources in this world. God as the main source of trust and resources possessed by stakeholders. In these resources a responsibility is attached to the use, means and objectives set by the Trustee. The mandate form of Shari'ah accounting manifests itself in the form of accountability. In the view of sharia 
enterprise theory concern is not only about individual interests (in this case shareholders), but also concerns the interests of wider stakeholders including God, Humans, and Nature. God is an almighty substance and is the sole purpose of human life. Placing God as the highest stakeholder, that is the purpose and nature of real life. (Triwuyono, 2007).

\subsection{Accountability and Transparency}

According to the decision of the Head of the State Administration Agency (LAN) No.589 / IX / 6 / Y / 99, accountability is defined as an obligation to provide accountability or to answer and explain the performance and actions of a person / legal entity / collective leadership of an organization to those who have rights or have the authority to ask for information or accountability. In layman, the application of the principle of transparency can be interpreted as the application of information disclosure, or conveying information both in the decision-making process and disclosure of material and relevant information regarding the company's activities.

Kusuma (2012) states, transparency is openness to all actions and policies taken by the government. The principle of transparency creates mutual trust between the government and the community through the provision of information and guarantees convenience in obtaining accurate and adequate information. transparency and accountability are concepts that are closely related to one another, because without transparency there can be no accountability. Conversely transparency will not be of much use without being equipped with accountability

\subsection{Amanah and Fathanah}

Etymologically trustworthy (linguistic approach) from Arabic in the form of mashdar (amina-amanat) which means honest or trustworthy. Whereas in Indonesian language trust means message, command, statement or wajengan. Trust according to the terminology (term) is something that must be maintained and maintained to arrive at the right to have it. Trustworthiness will give birth to honesty and responsibility in carrying out tasks. Because no matter how small the task is carried out, the 
responsibility is not just to humans who can sometimes be deceived and deceived but to Allah SWT, a shat that will never forget any activity performed by his servant (Maulana, 2008). Allah SWT said in Al-Qur'an Surah An Nisa verse 58, namely:

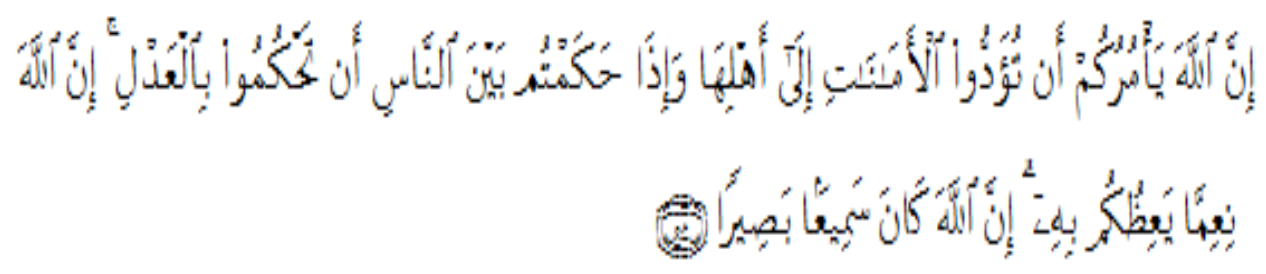

Translation:

"Verily, Allah has commanded you to deliver the message to those who have the right to receive it, and (tell you) to establish laws among men so that you will determine justly Indeed, Allah gives the best teaching to you. Verily, Allah is omniscient, all see.

Accountability in a trustworthy perspective is not only about accountability in the world, but also accountability in the hereafter (Selpiana, 2015). The principle of Amanah is also in accordance with the hadith of Abu Hurairah RA narrating, that the Prophet Muhammad said:

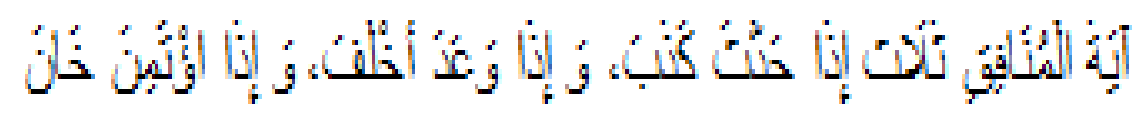

Translation:

"There are three signs of hypocrites; if he speaks he is lying, if he promises he denies, and if he is given the mandate he is a traitor "(HR. Al-Bukhari. No. 33)

The Fathanah meaning of "lughat" is intelligent, clever or clever, while the meaning of the term is cleverly adjusting itself in relation to when to say something. Derived from the Arabic language Al-fathanah or al-fithnah, which means intelligent, also has the same meaning as al-Fahm (understand) the opposite of al-ghabawah (stupid). This trait will foster creativity and innovation, it is only possible to have it when someone is always trying to add a variety of knowledge, regulations and information both related to work and public companies. The fathanah attitude can be 
seen as a strategy for the life of every Muslim. A Muslim must optimize all the potential that has been given by him to reach the Kholiq. One of the characteristics of the most cautious is people who are able to optimize their potential thinking as ulul alalbab, namely people whose faith and knowledge interact in a balanced way (Muzammil, 2001). Allah SWT even gave a strong warning to people who did not use their wits as described in Al-Qur'an Surah Yunus verse 100:

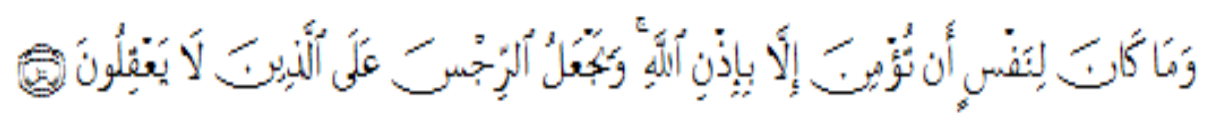

Translation:

"And no one will believe except with the permission of Allah; and God inflicts wrath on those who do not use their minds "

Sharia business people also have an intelligence (fathanah) or smart, smart and wise with the aim that their business can be more effective and efficient and able to analyze competitive situations (complete settings) and changes (changes) in the future (Zahroh, 2015).

\subsection{Thinking Framework}

The mindset in this study was compiled with the issue of non-profit financial management where many people were antipathetic towards mosques, because mosque administrators were not transparent in providing financial reports and bad mosque management causing many mosque congregations to leave. Another problem that often arises is that there are still many mosques that do not record details of cash receipts and disbursements, usually only recorded as cash receipts and expenditures without specifying sources of cash income and the use of mosque cash for anything, so that this sometimes arouses suspicion among the public. With this issue, a very related theory is the Sharia Interprise Teory which explains that all actions must prioritize the public interest and make God the main stakeholder so that the financial management actors of the mosque have a self-awareness of the mandate given by the 
community, because Amanah will give birth to honesty and responsibility in carrying out tasks.

Accountability arises as a result of giving trust (trust) from one party to another to carry out certain tasks. the manager of mosque finance must also have the principle of Fathanah who must have intelligence and skill in managing the finances. Fathanah means to understand, understand and deeply appreciate everything that happens in duties and obligations. With the implementation of obligations in the form of accountability and transparency that are processed intelligently, it will then produce quality financial reports. Broadly speaking, the scope and scope of a complete and comprehensive in this study, looks at the research framework presented Figure 1.

\section{Picture 1}

Frame of mind

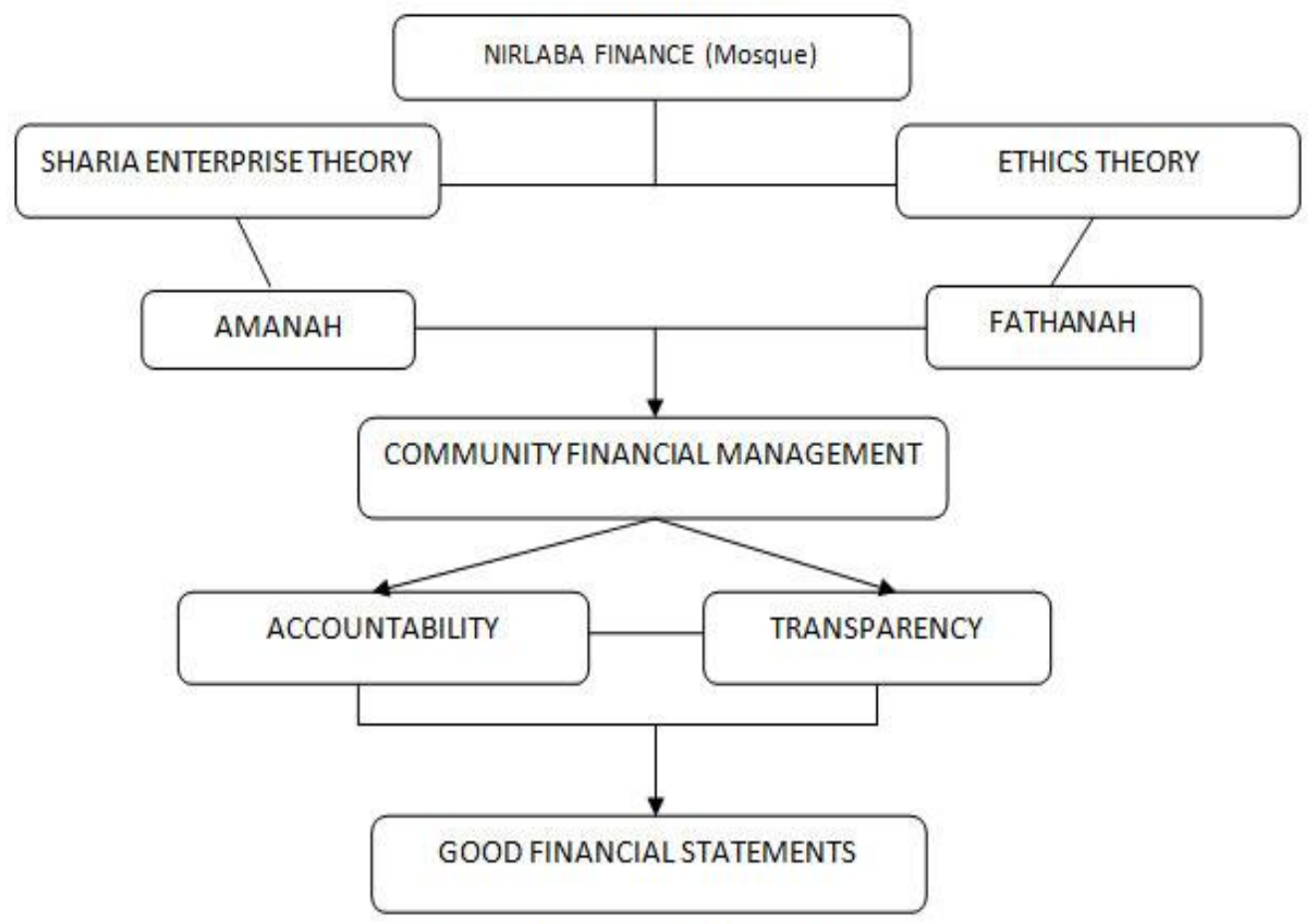

Source: Documentation. 2017 


\section{Research Method}

\subsection{Type and Location of Research}

This study is dominated by using qualitative research data (primary data), using the phenomenology approach. This research was conducted at the Istiqomah Mosque located in Nganjuk Hamlet, Sugihwaras Village, Wonomulyo District, Polewali Mandar District, West Sulawesi Province.

\subsection{Research Approach}

This study uses a phenomenological approach. According to Maleong (2006: 14) in Mulia (2012) Phenomenology is a subjective experience or phenomenological experience, or a study of consciousness from the main perspective of a person. Phenomenology is also a form of confusion about the meaning of one's experience, so something about someone's experience will depend on how people relate to something. This study explains the existing phenomena by developing concepts and gathering facts through data as a means of support. In this study there are two conceptual components, namely amanah and fathanah. The purpose of this approach is to uncover facts, circumstances, phenomena, which occur when the research goes in line with the problem statement.

\subsection{Data Collection Technique}

The implementation of this research requires research data, in research data collection techniques are an important factor in the success of research. This relates to how to collect data, who the source is, and what tools are used, where to collect the required data, two methods are used, namely the primary method and the secondary method. The data collection methods used in this study are as follows:

a. Deep interview

Interviews are used as data collection techniques if researchers want to conduct a preliminary study to find problems that must be investigated and also if researchers want to know things from respondents who are more indepth. It can also be said that interviews are face to face conversations 
between interviewers and source of information, where the interviewer asks directly about an object being researched and has been designed. In-depth interviews were conducted directly with the informants separately in their respective environments. Interviews were conducted with informants who were considered competent and representative.

b. Literature review

Library study is a technique of collecting data by conducting searches using references from books, journals, papers and legislation related to the object of research to obtain concepts and data relevant to the problems studied as supporting research.

c. Documentation Study

Documentation study is a collection of data in the form of secondary data in the form of social documents from the institution. Documents can be in the form of writing, drawing, or monumental works of someone as a supporting tool to strengthen data.

d. Internet searching

Internet searching is a study conducted by collecting various additional references sourced from the internet to complete the author's reference and used to find facts or theories relating to the problem under study.

\subsection{Research Informant}

In this study using criteria in determining informants. The criteria are based on certain characteristics which are considered to have a close relationship with the characteristics of the population that were previously known, in other words the sample units are adjusted to certain criteria based on the research objectives. The criteria in determining informants such as mosque management, knowing about mosque finances, mosque congregation are active, and must be willing to be interviewed. Based on these criteria, the researcher determines the informants, namely: 
Table 1

Research Informant

\begin{tabular}{|c|c|c|c|}
\hline No & Name & Agency & Position \\
\hline 1 & Sunaryo & Istiqomah Mosque & Treasurer \\
\hline 2 & Muh. Agus & Istiqomah Mosque & Teenage chair \\
\hline
\end{tabular}

Source: istiqomah mosque administrator

\subsection{Data Analysis Method}

In this study using data analytical techniques that are in accordance with the phenomenology approach as stated by Mulia (2012) there are four stages in fenomelogy analysis techniques, namely:

a. Describing phenomena from interviews that have been recorded interview transcripts identifies phenomena from the interviews that have been recorded.

b. Identify the theme that appears from the description in the first stage.

c. Develop noem and noesis.

d. Witness the essence of the correlation between noema and noesis.

\section{Results and Discussion}

\subsection{Overview of Research Sites}

Istiqomah Mosque was founded in 1940 occupying waqf land. at first this mosque was located in a place 100 meters away from the place where the mosque is now being moved on the grounds that the previous mosque was small to accommodate residents. The development process is still focused on physical development but does not forget about the personal development. As stated by one of the administrators of the mosque of Mr. Sunaryo when talking lightly after Friday prayers said that:

"... here, I still want to continue to build this mosque, hopefully a lot will contribute, but why should I build a mosque if it is not built by the people, including the teacher of the ji Koran, it will be repaired? 
From the statement of the management of the Istiqomah Mosque, we can see that in the perspective of the Management, it still strongly prioritizes the physical development of the mosque because the mosque is still relatively new. However, by prioritizing physical development, the Istiqomah Mosque does not forget about building the quality of semisal worship. Istiqomah Mosque has maximized the teaching process of the Koran conducted at the mosque and has young mosques involved directly in financial management.

\subsection{Mosque Organizational Structure}

Istiqomah Mosque is a mosque that has only been occupied for more than a year but with this period the construction of the mosque is relatively fast, as a mosque whose new organizational structure is still very simple it only concerns the imam of the mosque, chairman of the building as well as treasurer, adolescent mosques and some who volunteered the mosque and together help each other in the financial management process as explained by Muhammad Agus, a youth mosque leader, stated.

What is the organizational structure in this mosque?

"... there is a structure, there are also those who are used to teaching recitation ... if I am a teenager, there is also the treasurer of the mosque and the head of the building committee ... but there is no new mosque installed yet"

From the explanation from the Chairperson of the Youth Mosque, it indicated that the Istiqomah Mosque still did not specialize in the duties of each of the administrators, the management only prioritized cooperation and mutual trust in the management of the Istiqomah Mosque. as for some parts of the mosque's committee and their respective duties, namely:

1) Imam of the Mosque

Imam of the mosque is someone who regulates all worship in the mosque, Imam Istiqomah Mosque has the duty as the organizer of the five prayer times in congregation, Friday Prayers, Eid Al-Fitr Prayers and Eid al-Adha, and Prayers. 
2) Builder committee and treasurer

The mosque building committee has the task of building the mosque's physicality, providing all facilities and infrastructure for worship, and building the faith and piety of the mosque's worshipers. Sunaryo is currently chairing the committee for the construction of the Istiqomah Mosque as Chair of the committee. the chairman of the development committee also serves as treasurer in managing the mosque's finances and the tasks are assisted by some subordinates or trustees.

3) Mosque Youth

The Istiqomah mosque adolescents are usually involved in the process of teaching the Koran and also as a helper to collect monthly donors who are tasked with entering residents' houses to solicit their sincere contributions for the construction of the Istiqomah Mosque.

\subsection{The Source of Funds for the Istiqomah Sugihwaras Mosque}

The main source of the Istiqomah Mosque still relies on monthly donors as explained by Sunarto.

What is the source of income for this mosque?

"This is as hard as the income from monthly donors who are billed by teenagers in mosques ... Friday piggy bank, charity box ... here the source is big yesterday, the debt here is $\mathrm{Rp} 100,000,000$, but Alhamdulillah, the salary is paid off"

There are several posts of istiqomah mosque income that are a source of funds for development activities and mosque activities, namely: Friday envelope, monthly donors and piggy banks but with such a high income istiqomah mosque is quite large.

4.4 Financial Accountability and Transparency of Istiqomah Sugihwaras Mosque Based on the Amanah Principle 
Accountability and transparency are very important in financial reporting as well as financial reporting, the Istiqomah Sugihwaras mosque is very important to see the financial condition of the mosque and the financial statements of the Istiqomah Sugihwaras Mosque should adhere to an Islamic principle because Accountability in an Islamic perspective gives understanding to we that accountability for the use of organizational resources is not only given to humans but also to God and nature (Kholmi, 2012).

Accountability and Transparency Activities The inclusion and expenditure of Istiqomah Sugihwaras Mosque and other mosque activities are carried out in various ways, including there are several posts of income and expenditure of Istiqomah Sugihwaras Mosque which are a source of funds for development activities and mosque activities, namely:

\section{a. Donations Every Friday}

Friday's donation was one of the sources of income for the Istiqomah sugihwaras mosque, and was also reported on Friday containing a report on the financial condition of the mosque construction for a week. Friday's report was delivered before the congregation on Friday before the preacher rose to the pulpit. The enthusiasm of the people who donated through Friday envelopes was very high as explained by Mr. Sunaryo earning from the Friday envelope during October 2017, namely:

Table 2

Donations every Friday

\begin{tabular}{|l|l|l|}
\hline No & \multicolumn{1}{|c|}{ Date and time } & \multicolumn{1}{c|}{ Total } \\
\hline 1 & Friday / 06-10-2017 & 517.000 \\
\hline 2 & Friday /13-10-2017 & 565.000 \\
\hline 3 & Friday /20-10-2017 & 1.700 .000 \\
\hline 4 & Friday /27-10-2017 & 859.000 \\
\hline & Total & $\mathbf{3 . 6 4 1 . 0 0 0}$ \\
\hline
\end{tabular}

Source: Istiqomah Mosque Management. 2017

Regarding supervision in calculating donations every Friday, the calculation is carried out by the treasurer or usually handed over to the mosque administrator 
and counted together with the Youth of the Mosque, and the calculation does not specify a time, but will only be calculated when the treasurer has free time. In this way, the calculation of donations every Friday does not make transparency to pilgrims. So that in this way can grow questions in every mosque congregation about the performance of the mosque administrator.

\section{b. Monthly Donors}

Monthly donors are the main source of income from istiqomah mosques, these regular monthly donors have been noted previously by the mosque committee to be asked every month through the dor to dor system. The activity was also carried out by four mosque mosques who were assigned to climb the stairs of each house that became monthly donors Istiqomah mosque. As explained by Mr. Sunaryo that:

"This is the monthly contribution of donors who ask that four teenagers of the mosque ... claim their sincerity"

Mr. Sunaryopun explained the monthly donors' income starting from September to October as follows:

Table 3

Monthly Donors

\begin{tabular}{|l|l|l|}
\hline No & Month & Total \\
\hline 1 & September & 3.350 .000 \\
\hline 2 & Oktober & 3.300 .000 \\
\hline & Total & $\mathbf{6 . 6 5 0 . 0 0 0}$ \\
\hline
\end{tabular}

Source: Istiqomah Mosque Management. 2017

Regarding supervision during the calculation of the results of this monthly donation, pilgrims were not involved in calculating the results themselves calculated by adolescents assigned to collect the donors and the number of results reported directly to the treasurer, using the system there was a gap to commit fraud in unsupervised calculations but by relying on the principle of mutual trust in the management as long as possible so that the hope of fraud will not occur in the collection of monthly donors. 


\section{c. Mosque Savings}

Mosque savings is a post that cannot be separated in the mosque's income, the calculation of the mosque piggy bank is usually counted together by the Mosque Committee and the mosque's youth and the piggy bank is combined with a Friday envelope and announced every Friday. Similarly, if there is a donation from the community or tanimaka group, it will be put into a piggy bank, as stated by Mr. Sunaryo:

"... yesterday there was also a donation from a farmer group but I gave it to the charity box so I counted the saving"

From the statement, it was explained that there was no separation especially in the entry of the Istiqomah Mosque, usually combining all income in one treasurer so that all expenses were taken from the mosque's cash, for example:

1) Shopping for mosque construction

Development expenditure is expenditure to finance all activities related to the construction, repair or maintenance of mosques. The source of funds to finance this activity is from the cash of the Istiqomah Mosque Construction Committee.

2) Shop for equipment

Mosque equipment is a means of supporting in worship activities. Examples of this are for example: sound systems, pulpits, air conditioners, cleaning equipment, lights, and others.

3) Electricity cost

All electricity costs were also taken from the previous mosque's cash Istiqomah Mosque also had special donors for electricity payments, as explained by Sunaryo said:

"... there are also first but stop because the payment is stagnant"

4) The cost of lectures, Koran teachers, Mosque priests, and donor collectors 
As for the salaries of mosque administrators the mosque administrators do not expect to get a salary from the mosque they work for purely sincerity as explained by Mr. Sunaryo as a mosque administrator:

"We are here not hoping for anything if we want to fix this mosque a long time ago we build a mosque because it is very small in the past here ... but also if the children go to collect every house there is no mercy so that the spirit also becomes every IDR 1,000,000 given Rp 50,000 per person, so the priest and the teacher recite and the muezzin is still commonly added too ... like the imam of the mosque there is a salary of Rp 150,000 every month but it is still usually in a Rp 500,000 patch so there is encouragement too ... muezzin is also added but it depends on the income of the mosque if there are remaining in the pakemi for the construction of the mosque "

Seeing information from the management of the Istiqomah Mosque was very concerned about the welfare of its administrators so that in the management of the mosque even the administrators had enthusiasm in carrying out their duties.

By applying the principle of trust in the financial reporting process well it will concern the trust of the pilgrims to the manager of mosque finance for the mosque's survival, the mosque administrators are aware that their duty is trust and worship to Allah SWT, they cannot get a salary in managing the mosque. We can see this in the interview with the Istiqomah Sugihwaras Mosque Committee who said:

As a mosque administrator what is the goal and how is the responsibility for the trust given to you?

"The goal is how this mosque so that many who come to the mosque we have built a mosque not for business, we worship how good it is to build 
a people. The mandate is that we really do it if we give the mandate to be transparent with the members"

From the interview fragments above, we can understand that the Treasurer of the Development Committee is aware that managing mosques, especially their finances, is worship that produces great rewards and the mosque is not a place to do business. This is an understanding born of trust in Allah. The realization that God will reward those who want to take care of His house. The position as a mosque treasurer that is heavy with various tasks such as securing and keeping books on mosque funds without salary and benefits certainly makes some people 'lazy' to take it. Moreover, the shadow of scorn and criticism from worshipers or the community if there is a little misunderstanding certainly makes people underestimate this position. However, because of the belief in the reward of God. The results of the interview also explained the value of tauhid for mosque administrators emphasizing that the purpose of human life is to worship and seek the pleasure of Allah, thus all resources must be mobilized to achieve the pleasure of Allah. All activities must be a form of worship to Allah SWT. We can find the value of monotheism on the management of mosque finance in terms of the awareness of the Mosque Construction Committee that their duty is trust and worship to Allah. They did not get a salary or honorarium for their services in managing the mosque.

Although the weight of the administrators of Nurul Amin Mosque and Istiqomah Sugihwaras Mosque is very responsible for the trust given to them Accountability and transparency can also be seen in their performance in managing the finances of the Istiqomah Sugihwaras Mosque well by dividing it into certain posts and taking good responsibility. both seen from reports from each Friday, the Amal Amal Friday report, electricity donors have been prepared as well as possible, although the management of the Istiqomah Mosque is still very simple, only recording income and expenses but they have fulfilled the mandate given to them, and the spirit and principles that the management uses has shown that their work in the form of worship to God and full 
responsibility only to God, while transparency has been based on the principle of good trust by reporting each of its income and expenses every Friday every Friday.

By taking full responsibility for the trust that has been given to them, the administrators are sure that by taking care of the mosque they obtain blessings from Allah. Administrators realize that taking care of mosques brings blessings from Allah and facilitates their sustenance. The following is a fragment of the interview with the Chairperson of the Committee for the construction of the Istiqomah Sugihwaras Mosque on this matter stating that:

"Yes ... if you become a mosque administrator it's a deck. two ji is obtained. First, people praise good mosques. Both stories of ordinary people behind, there are also those who commonly criticize. But we have held deliberations for the construction of mosques. If the benefits themselves, I personally feel like there is a blessing in my business to be smooth. Anyway like there is a blessing from God and that is because maybe I take care of the mosque"

As well as avoiding criticism from the committee members, they were very careful in the use of mosque funds. Caution in using mosque funds can be seen from the principle of not living the mosque. It can be seen in the attitude of the Mosque Administrators who do not take gasoline or credit in managing activities. the mosque. The following is a part of the interviewer's interview with the Chair of the Development Committee regarding this matter.

\section{What is the challenge in managing a mosque?}

"There is no challenge if managing a mosque is a challenge which means it is not sincere. we build mosques not for business, we worship how good it is to build the people ... the administrators do not expect to be paid but want to love so that there is enthusiasm as the donor donors are paid as well, the imam of the mosque is also added if there are new uses built"

From the interview fragments above, we can understand that managing a mosque does require sincerity and sacrifice for the progress of the Mosque. In the absence of remuneration for the hard work of the committee in building the mosque, of course, they will only receive God's reward. 
In addition, based on the interview fragments above, we can also understand that managing a mosque means building and prospering the house of God. Mosques must always be in the process of physical and non-physical development. Then physical development will not stagnate. There must always be a mosque that needs to be repaired. There is always a need for worshipers who must be fulfilled by the management. Thus, it is true what was said by the Chair of the Development Committee that there were no mosques that had been made. And the welfare of the administrators is very concerned so that the management has enthusiasm in work.

In addition, based on the fragment of the interview above, we can also understand that taking care of the mosque means continuing to build and prosper the house of God. Mosques must always be in the process of physical and non-physical development. Then physical development will not stagnate. There must always be a mosque that needs to be repaired. There is always a need for worshipers who must be fulfilled by the management. Thus, it is true what was said by the Chairperson of the Development Committee that there were no mosques that had been made. The welfare of the administrators must be considered, so that they have a high enthusiasm in work.

The trust they received was not solely to account for one another but also for God. Accountability to God means an awareness of nature that places God (God) as the highest principal (Kholmi, 2012). This means that the mosque administrator should prioritize God's desire in managing the mosque. Information about God's wishes in terms of managing the mosque is contained in His holy book and the Sunnah of His Messenger. God himself wants the mosque to be a place where His name is called. Described in Al-Quran surah an-nur verse 36:

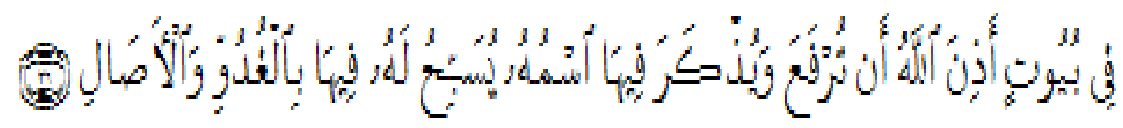

Translation:

[Male] exaltation to Allah in mosques that have been commanded to be glorified and called His name in it, in the morning and evening.

This means that mosques must routinely hold congregational prayer meetings with many worshipers. Mosques must always be open to worshipers, the community 
or travelers who want to stop worshiping or recite dhikr. Another meaning of this verse is also that the mosque should be a place where the greatness of God is told. The mosque became a mouthpiece where God's commands and prohibitions were delivered. In addition, Allah also expects that believers will prosper the mosque, not until the mosque is quiet, the idolaters who then prosper the Mosque as described in the Qur'an surah At-Taubat verses 17-18:

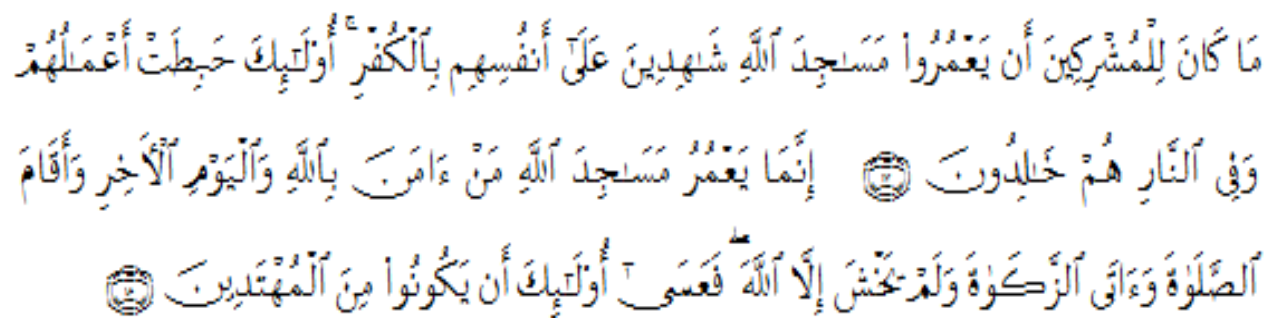

Translation:

It is inappropriate for the polytheists to prosper the mosques of Allah, while they admit that they themselves are infidels. Those who are in vain work, and they are eternal in hell (Q. 9: 17).

Only those who prosper the mosques of Allah are those who believe in Allah and later, and continue to establish prayers, perform zakat and not be afraid (to anyone) other than Allah, then they are the ones who are expected to belong to the group of people get instructions (Qur'an 9: 18).

From the quran's explanation, it is explained that Prosperity of the mosque means building the mosque's physicality, coordinating the worship activities in it, carrying out religious activities, education and other beneficial activities. With the beliefs and values that they apply and assume that their position is not as their source of income but as a form of worship to Allah SWT as explained (Mulawarman, 2009: 126) Human duty as a trustee in a business perspective is explained showing two main forms. First, in the Shari'ah view, it is not just business, but it is a kind of worship that not only includes economic transactions, but also a sense of mutual help (society in general), caring for the environment and a sense of love for God. 


\subsection{Accountability and Transparency of Istiqomah Sugihwaras Mosque Based on Fathanah Principles}

In the management of mosque commentators demanded to have the principle of fathanah (smart). Someone who has fathanah nature, his decisions show the color of proficiency of a professional based on moral attitudes or noble character (Maulana, 2008). So that with these characteristics the mosque administrators will be wise and smart in handling these sources of income. This trait will foster creativity and innovation, it is only possible to have it when someone always tries to add a variety of knowledge, regulations and good information related to his work.

Management of mosque finance and resources must be used efficiently and effectively (Pralebda, 2013). Efficient means that the management of mosque finance must be as economical as possible. One efficient attitude is cost minimization. The administrator of the Istiqomah Sugihwaras mosque has tried to be efficient in managing pilgrims' funds. This can be seen in the attitude of the Treasurer of the Development Committee who wrote the Friday report hand on used HVS paper. Though with a cash balance that many administrators can buy new paper. The second criterion is effective. Efficient attitude is not complete without an effective attitude. Effective is the attitude that uses mosque resources as optimally as possible to achieve goals. An example of an effective attitude is the attitude of the mosque administrator who spends mosque money for the installation of air conditioning so that pilgrims are more comfortable in performing worship. The Istiqomah Mosque also does this, installing air conditioners for the convenience of worshipers. Thus, the mosque administrators of Istiqomah have tried to be effective and efficient.

The Istiqomah Mosque whose note is the newly built mosque has an ordinary administrative structure and multiple positions in the mosque management so that the management of the mosque's finances is not good, as explained by Muhammad Agus as the mosque's youth leader said:

"... there is the structure, there are also those who usually teach recitation ... if I am a teenager, there is also the treasurer of the mosque and also the chairman of 
the building committee ... it is already there but it has not yet been installed, this new mosque will be done anyway"

From the information, the Istiqomah Mosque, which is a newly occupied mosque, only runs very simple arrangements and lacks computational human resources to manage mosques, resulting in multiple positions in the management of the Istiqomah Mosque. Mosque administrators do not yet know how to manage the mosque well, so that the financial management of the Istiqomah Mosque is still very simple and still only includes income and expenditure, with the successors of the Istiqomah Mosque still not applying the fathanah principle in managing their mosque's finances. The absence of a definite board structure, the manager of the Istiqomah Mosque is quite clever with the availability of monthly donors that are certain and will be billed every month. Door to door system, involving Youth Mosques to be assigned to collect the monthly donors, as explained by Mr. Sunaryo that:

"This is the mosque's production from monthly donors who collect that four mosque mosques ... collect their credit ... there are records at home, ... mosque mosques who collect salaries are also paid every IDR $1,000,000$ given IDR 50,000"

Mr. Sunaryo publishes monthly donors' income starting from September to October in table 4.

Table 4

Monthly donors

\begin{tabular}{|l|l|l|}
\hline No & Month & Total \\
\hline 1 & September & 3.350 .000 \\
\hline 2 & Oktober & 3.300 .000 \\
\hline & Total & 6.650 .000 \\
\hline
\end{tabular}

Source: Istiqomah Mosque Management. 2017

In the welfare of its members the Istiqomah Mosque Administrators also strongly applied the fathanah principle seen from the very wise by paying attention to its members, as explained by Mr. Sunaryo stating that: 
"... but it's too bad if children go to collect every house there is no mercy so

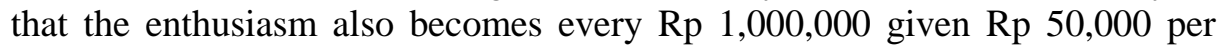
person, so the priest and teacher recite and muezzin is usually added too ...

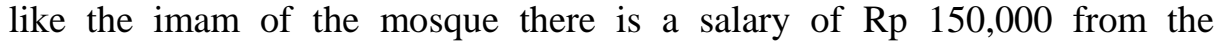
government every month but it is still normal to use a 500,000 IDR to have a boost too, ... muezzin is also usually added but depends on the income of the mosque if there is the rest in the mosque for the construction of the mosque "

The results of the interview explained that the Istiqomah Mosque explained that the mosque administrators were very wise and very respectful of their members in managing the mosque's finances, so that this would increase the spirit of the members in managing the mosque's finances.

The transparency of the istiqomah sugihwaras mosque, a mosque which has only been occupied for more than a year, does not use effective methods to increase public trust in mosque administrators in managing the mosque's finances. Istiqomah Mosque in carrying out its transparency only relied on announcements every day before Friday prayers, mosque administrators still relied heavily on each other's trustees such as calculating donations every Friday the calculations were carried out by the treasurer or usually handed over to mosque administrators and counted together with mosque adolescents and their calculations do not set a time but will only be calculated when the treasurer has free time. As explained by the mosque administrator that:

"Treasurer who counts but usually the caretaker is the same as the Teen Mosque who counts because the treasurer is usually busy"

Certainly by this way the calculation of donations every Friday does not make transparency to the pilgrims. So that this method can grow questions in every mosque congregation about the performance of mosque administrators. Similar to the calculation of the results of the monthly donors made by the mosque's youth, the pilgrims were not involved in calculating the results, the results were calculated by the youth who were assigned to collect the donors and the results were reported directly to the treasurer, using the system there was a gap to do cheating in unattended calculations but by relying on the principle of mutual trust in the entire management 
so that the expectation of fraud will not occur in the collection of monthly donors. In this way new mosques according to researchers are still reasonable because donors are still enthusiastic in contributing, but if this continues, it is not impossible that the mosque's doubts about the financial managers of the Istiqomah mosque will be questioned.

\section{Conclusion}

Istiqomah Sugihwaras Mosque has carried out accountability and transparency based on the mandate principle by carrying out the Enumeration of all income and expenditure as for Transparency has been carried out such as reporting each income and expenses every Friday every Friday. In its financial management process the Istiqomah Mosque still does not apply the fathanah principle, it can be seen from the unclear management structure, only recording expenses and revenues and transparency only relying on announcements every Friday and the calculation of funds only involves administrators without involving pilgrims so that this will reduce the degree of trust worshipers towards mosque administrators in managing mosque finances, but for the organization's continuity the mosque committee was very wise with the addition of salary incentives to the Imam of the Mosque and the Khatib Mosque.

Lack of competent human resources in managing mosque finances is good, so much needed training or guidance in financial management especially non-profit financial institutions and mosque organizations are willing to be transparent, but so far the practice of transparency in mosques is still not optimal because information about mosque management stored for internal organization and announcing financial statements verbally as a "symbol" of the form of transparency so it is very much needed by the use of media such as bulletin boards as a means to communicate the performance results of mosque takmir so that the public knows and evaluates the results of organizational performance management and provision of books Suggestions and suggestion boxes are placed in strategic locations where people are easier to access. 


\section{References}

Ansar, D dan Mukhtar. 2010. Akuntansi dan Pengelolaan Keuangan Masjid di Masjid (Sebuah Studi Kasus). Universitas Sultang Ageng Tirtayasa. Serang

Bastian, I. 2005. Akuntansi Sektor Publik: Suatu Pengantar. Erlangga. Jakarta

Diptayani, P. (2009). Studi atas Praktik Akuntansi di Organisasi Mesjid Surabaya. STIE Perbanas. Surabaya

Endahwati, Y, D. 2014. Akuntabilitas Pengelolaan Zakat, Infaq, Dan Shadaqah (Zis). Jurrnal Ilmiah Akuntansi dan Humanika (JINAH). 4(1)

Haq, J. A dan Miranti, K. D. 2013. Praktik Manajemen Keuangan Mesjid dan Potensi Dana Mesjid (Studi Kasus pada Beberapa Mesjid di Kota Bogor). Praktik Manajemen.

Kusuma, M. 2012.Pengaruh Akuntabilitas Terhadap Transparansi Penyusunan Laporan Keuangan Pemerintah Daerah (Studi Empiris Terhadap Persepsi Mahasiswa Diploma Akuntansi Di Kediri). 2(2): 45-57.

Kholmi, M.2012. Akuntabilitas dan Pembentukan Perilaku Amanah Dalam Masyarakat Islam. Jurnal Reviu Akuntansi dan Keuangan. 15(1): 63-72

Mulawarman, A. D. 2009. Akuntansi Syariah teori,konsep dan laporan keuangan. E Publishing Company. Jakarta

Mulia, A, S. 2012. Mengungkap Pemahaman tentang Akuntansi dari Kecerdasan Emosional, Spiritual dan Sosial Mahasiswa. Jurnal Akuntansi Multiparadigma. 3(3):334-501.

Maulana, A. 2008. Implementasi Konsep Amanahdan Fathanah pada Pengelolaan Zakat Badan Amil Zakat Nasional (BAZNAS). Skripsi. Uin Hidayah Tullah.

Muzammil, M.E dan Muhammad, S. Penerapan Siat-Sifat Nabi SAW dalam Perbangkan Syariah. http://berbagiidedanpikiran.blogspot. com/2011 /12. Penerapan- Siat-SifatNabi- SAW-dalam-Perbangkan-Syariah.html. Diakses pada 23 Agustus 2017: 05.43 Wita.

Selpiana, I dan Muhammad, I. 2015. Konservatisme Akuntansi, Efektivitas Komite Audit, Konsep Amanah Dan Manajemen Laba. Universitas Muhammadiyah Jakarta.

Pralebda, G. 2013. Pengelolaan Dana Masjid yangAmanah. Online. http:www. almuqarrabinwp.com. Diakses pada 24 Oktober 2017: 22. 30 wita.

Triyuwono, I. 2007. Mengangkat "sing liyan " untuk Formulasi Nilai Tambah Syari'ah. Simposium Nasional Akuntansi X Unhas. 1-21.

Triyuwono, I dan Mohammad, A. 2001. Akuntansi Syariah Memformulasikan Konsep Laba dalam Konteks Metafora Zakat. 